\title{
Effects of water stress on growth, dry matter allocation and water-use efficiency of a leguminous species, Sophora davidii
}

\author{
F. L. Li • W. K. Bao $\cdot$ N. Wu
}

Published online: 3 September 2009

(C) Springer Science+Business Media B.V. 2009

\section{Erratum to: Agroforest Syst DOI 10.1007/s10457-008-9199-1}

Author would like to update the two references as given below:

Li FL, Bao WK, Pang XY et al (2009) Seedling emergence, survival and growth of five endemic species in the dry valley of Minjiang River. Acta Ecol Sin 29(5):2219-2230 (in Chinese, with English abstract)
Namirembe S, Brook RM, Ong CK (2009) Manipulating phenology and water relations in Senna spectabilis in a water limited environment in Kenya. Agrofor Syst 75:197-210
The online version of the original article can be found under doi:10.1007/s10457-008-9199-1.

F. L. Li · W. K. Bao · N. Wu (ه)

Chengdu Institute of Biology, Chinese Academy

Sciences, P.O. Box 416, Chengdu 610041,

People's Republic of China

e-mail: wuning@cib.ac.cn 